\title{
Kentsel Dönüşüm ve Kentsel Stres Kavramlarının Olası İlişkileri
}

\author{
Ece Özmen ${ }^{1 *}$, Tolga Kayacan ${ }^{2}$ \\ 1* Manisa Celal Bayar Üniversitesi, Salihli Meslek Yüksek Okulu, Toptan ve Perakende Satış Bölümü, Emlak Yönetimi Programı, Manisa, Türkiye (ORCID: 0000- \\ 0003-0769-9777), ece.ozmen@.cbu.edu.tr \\ 2 Şehir Plancisı, Dr. (ORCID: 0000-0003-0818-277X), tolga_kayacan@yahoo.com
}

(İlk Geliş Tarihi 25 Mart 2021 ve Kabul Tarihi 5 Temmuz 2021)

(DOI: 10.31590/ejosat.903517)

ATIF/REFERENCE: Özmen, E. \& Kayacan, T. (2021). Kentsel Dönüşüm ve Kentsel Stres Kavramlarının Olası İlişkileri. Avrupa Bilim ve Teknoloji Dergisi, (25), 657-664.

\begin{abstract}
$\ddot{O} z$
Geçmişten günümüze kentler sürekli değişimin ve dönüşümün yaşandığı, inşaat odaklı bir dinamizme sahip, yerleşim alanları olmuşlardır. Kentsel dönüşüm, kentlerin bu dinamik yapısına doğrudan cevap veren bir uygulama olarak ülkemizde ve Dünya'da sıkça kullanılmaktadır. Kentsel stres etkilerinin kentin dinamizmine bağlı olduğu gerçeği gibi kentteki dönüşüm hareketlerinin de kentsel stres üzerinde etkisi bulunmaktadır. Özellikle insan sağlığının ve yaşam kalitesinin ön planda tutulduğu sürdürülebilir ve ekolojik eksenli kentsel dönüşüm çalışmalarının kentsel stresi azalttığını söylemek mümkündür. Hazırlanan bu araştırma çalışmasında, kentsel stres ve kentsel dönüşüm arasındaki ilişki kentsel dönüşümün amaçları ve boyutları üzerinden incelenmekte olup başarılı bir kentsel dönüşüm uygulaması olarak görülen Bo01 Malmö kentsel dönüşüm projesi üzerinden kentsel stresin azaltılmasına yönelik uygulamaları incelenmektedir. Bo01 projesi sürdürülebilir ve ekolojik kentsel dönüşümün bir örneği olarak ele alınmakta ve atıl kalan bir alanı yeniden işlevsel hale getirerek kentsel stresin azaldığı bir yaşam alanı haline geldiği görülmektedir. Sonuçta başarılı ve yaşam kalitesini arttıran, toplumun tümü üzerinden fayda yaratabilen kentsel dönüşüm uygulamaları ile atılacak adımların, kentsel stresi azaltması mümkündür. Uygulamada Bo01 Malmö projesi gibi başarılı örnekler ile kentsel stres faktörleri göz önünde bulundurularak kentsel dönüşüm projeleri yeniden ele alındığında kentsel stresi azalacak olup yaşam kalitesini de artacaktır.
\end{abstract}

Anahtar Kelimeler: Kentsel Stres, Kentsel Stres Faktörleri, Kentsel Dönüşüm, Kentsel Dönüşüm Amaçları ve Boyutları, Bo01Malmö

\section{Possible Relations of Urban Regeneration and Urban Stress Notions}

\begin{abstract}
From past to present, cities have been residential areas with a construction-oriented dynamism, where constant change and transformation are experienced. Urban transformation is frequently used in our country and in the world as an application that directly responds to this dynamic structure of cities. The fact that the effects of urban stress depend on the dynamism of the city, the transformation movements also have an effect on urban stress in the city. Sustainable and ecologically oriented urban transformation studies, especially in which human health and quality of life are prioritized, reduce urban stress. In this research article, the relationship between them is examined through the purposes and dimensions of urban transformation, and its applications to reduce urban stress are examined through the Bo01 Malmö urban transformation project. Bo01 project stands out as an example of sustainable and ecological urban transformation, and it has become a living space where urban stress is reduced by increasing the quality of life of the citizens by making an idle area functional again. As a result, it is possible to reduce urban stress with successful urban transformation practices that create benefits for the entire society. Considering successful examples such as the Bo01 Malmö project and urban stress factors in practice, urban regeneration projects will decrease and the quality of life will increase.
\end{abstract}

Keywords: Urban Stress, Urban Stress Factors, Urban Transformation, Urban Transformation Goals and Dimensions, Bo01-Malmö

\footnotetext{
*Ece Özmen: ece.ozmen@,cbu.edu.tr
} 


\section{Giriş}

Kentler, toplumun bir ürünü olarak dinamik, kozmopolit, karmaşık ve değişken bir yapıya sahip yaşam alanlardır. Son 30 yılda giderek artan kentleşme hızı ile birlikte kentlerdeki sosyal çevre ve yapılaşmış çevre hızlı bir değişim göstermiştir. Yeşil ve açık alanların azalması, kentlerdeki sıkışmışlığın yarattığ1 çevresel ve sosyal sorunlar, hava kirliliğinin artması gibi nedenler kentsel stresi de arttırmaktadır. Kentte yaşanan her durum ve olay bir yönüyle toplumda oluşturduğu kentsel stres şeklinde gündem haline gelmektedir.

Stres, insan sağlığını fiziksel veya ruhsal olarak etkileyerek, yaşam kalitesi üzerinde doğrudan etkin bir faktördür. Kentsel stres ise kesin ve net bir tanımı olmamakla birlikte Koene'e göre birçok farklı faktöre bağlı olarak kentli yaşantısında etkili olmaktadır (Koene, 2018). Alt faktörleri ile birlikte ele alındığında planlama yaklaşımlarının her zaman çözüm bulmaya çalıştığı birçok sorunun stresi tetiklediği de görülmektedir. Stresin yanı sıra sağlıksız koşullarda yaşayan bireyler, koşullarının iyileştirilmesi için sürekli bir destek beklemekte olup kentsel dönüşüm uygulamalarını bir firsat olarak görmektedir.

Kentsel dönüşüm uygulamaları günümüzde, sanayi alanlarının şehir dişında yer gösterilmesi nedeniyle boşaltılan yerlerin toplum yararına göre düzenlenmesi, kentlerde çöküntü bölgeleri olarak öne çıkan alanların toplumsal ve fiziksel açıdan yaşanabilir, sağlıklı alanlar haline getirilmesi, eskimiş kent dokularının yeniden yapılandirılması ve afet sonrasında oluşabilecek hasarlara karşı riski olan alanların iyileştirilmesi olarak karşılık bulmaktadır (Yedekçi, 2015). Bütün bu uygulamaların sorunlara çözüm arayan ve daha yaşanabilir kentler oluşturmak için belirlenen planlama yaklaşımları ile uygulanan başarılı kentsel dönüşüm projelerinde kentsel stresin azaldığı görülmektedir.

$\mathrm{Bu}$ başarılı kentsel dönüşüm projeleri Dünya genelindeki kentsel dönüşüm projelerine örnek teşkil etmenin yanında, toplumsal yaşam kalitesini de arttırmaktadır. Bu çalışma kentsel strese yol açan faktörler ile kentsel dönüşümün amaçları ve boyutları arasındaki ilişkisini ortaya koymak amacıyla hazırlanmış olup Dünya'da başarılı bir kentsel dönüşüm uygulaması olarak görülen Bo01/Malmö projesi üzerinden ele alınmıştır. Sonuç olarak, doğru planlanan ve ilkesel yaklaşımları sayesinde başarılı bir kentsel dönüşüm uygulamasının kentsel stresi azaltıcı ve yaşam kalitesini arttırıcı bir araç olacağı sonucuna varılmıştır.

\section{Kentsel Stres ve Kentsel Stres Faktörleri}

Stres kavramı sağlık bilimleri yönüyle ele alınan bir kavram olarak bireyin kendisinde meydana gelen değişimleri ele almakla birlikte kentsel stres, bireyin yaşadığı bireysel baskı hissinden ziyade, toplumun (kentlilerin) genelinde yarattığ1 etkiler ve bask1 ile ilgilenmektedir. Kentsel stres seviyesi arttıkça toplumda oluşturduğu memnuniyetsizlik düzeyi o kadar artış göstermektedir. Kentsel strese yol açan faktörler araştırmacılar tarafindan farklı olarak ele alınsa da, bu faktörleri genel olarak kentsel çevreden kaynaklanan faktörler, kentlerin durumundan kaynaklanan faktörler, ekonomik kentsel faktörler, sosyal yaşam kaynaklı faktörler ve sağlık faktörleri olmak üzere beş ana başlikta toplayabilmek mümkündür (Tablo 1).

$\mathrm{Bu}$ beş temel faktörün alt başlıkları detaylandırıldığında, kentsel çevreden kaynaklı faktörlere örnek olarak kalabalık, etrafa dağılmış çöpler, yüksek katlı yapılaşma, trafik, kazalar ve yeşil alanların varlığı ve ulaşılabilirliği verilebilir. Kentsel yaşam koşullarından kaynaklı faktörler ise hava ve gürültü kirliliği, sıcaklık ve gün 1 şı ̆̆ yetersizliği olarak karşımıza çıkmaktadır. Sosyal yaşam faktörleri; cinsiyet eşitsizliği, ırk ayrımcılığı, suç oranları, sosyal destek ağlarının yetersizliğidir. Ekonomik faktörler; işsizlik, sosyal güvence ve satın alma gücü olarak değerlendirilebilir. Sağlık faktörleri ise ruhsal sağlık, fiziksel sağlık, beslenme, egzersiz yetersizliği, obezite ve virüslere açık olma durumlarını kapsamaktadır. Bütün bu temel faktörler ile bu faktörlerin alt faktörlerin en az birinden veya çok daha fazlasından bireyler (toplum) her gün etkilenmektedir. Kentsel stres faktörleri, plan kararları yanı sıra uygulama projelerinin niteliğine bağlı olarak stres seviyesini azaltabilir veya arttırabilir. Stres seviyesinin azaltılmasına yönelik atılacak bütün adımlar, gelecekte de kentlilerin yaşam kalitelerine etki edecektir.

Tablo 1. Kentsel Strese Yol Açan Faktörler (Koene, 2018)

\begin{tabular}{|c|c|}
\hline $\begin{array}{c}\text { Kentsel Stres } \\
\text { Faktörleri }\end{array}$ & Alt Faktörler \\
\hline $\begin{array}{l}\text { Kentlerin } \\
\text { Durumundan } \\
\text { Kaynaklı Faktörler }\end{array}$ & $\begin{array}{l}\text { Güneşin görüldüğü saatler } \\
\text { Hava kirliliği, Gürültü kirliliği, Iș1k kirliliği } \\
\text { SO2 (kükürt dioksit)'ye maruz kalma, NO2 (azot dioksit)'ye maruz kalma, Radyasyona maruz kalma } \\
\text { İklimsel ve jeofiziksel tehlikeler }\end{array}$ \\
\hline $\begin{array}{l}\text { Kentsel Çevreden } \\
\text { Kaynaklanan } \\
\text { Faktörler }\end{array}$ & $\begin{array}{l}\text { Yoğunluk, Kalabalık, Sıkıcı mega yapılar, Yüksek yapılar, Mimari ve kentsel tasarım düzenleri, } \\
\text { Çöpler, duvar yazıları, bakımsızlık, Trafik sıkışıklı̆̆ı, Otopark problemleri, Toplu taşıma, Güvenlik algısı } \\
\text { Yeşil alanların varlığı \& ulaşılabilirliği, Konut koşulları, Kazalar, Düşmeler }\end{array}$ \\
\hline $\begin{array}{l}\text { Sosyal Yaşam } \\
\text { Kaynaklı Faktörler }\end{array}$ & $\begin{array}{l}\text { Cinsiyet eşitsizliği, Irk eşitsizliği } \\
\text { Güvenlik hissi, Suç \& Hırsızlık } \\
\text { Sosyal destek ağlarının yetersizliği }\end{array}$ \\
\hline $\begin{array}{l}\text { Sağlık Kaynaklı } \\
\text { Faktörler }\end{array}$ & $\begin{array}{l}\text { Ak1l sağlı̆̆ } \\
\text { Fiziksel sağlık, Mikrop, bakteri ve virüslere maruz kalma } \\
\text { Beslenme, Obezite, Egzersiz yetersizliği }\end{array}$ \\
\hline $\begin{array}{l}\text { Ekonomik Kentsel } \\
\text { Faktörler }\end{array}$ & $\begin{array}{l}\text { İşsizlik, Kişi başına düşen borç } \\
\text { Sosyal güvenlik } \\
\text { Aile satın alım gücü }\end{array}$ \\
\hline
\end{tabular}




\section{Kentsel Dönüşüm Kavramı, Kentsel Dönüşümün Amaçları, Boyutları ve Yöntemlerinin Kentsel Stresin Azaltılmasındaki Etkileri}

Kentsel dönüşüm kavramının akademik ve mesleki hayatta birçok farklı tanımı bulunmakla birlikte, tüm tanımları genel olarak kentin eskimiş, yıpranmış, işlevini yitirmiş ya da sağlısız ve kullanışsız hale gelmiş alanlarının temizlenmesi, yapıların iyileştirilmesi, daha iyi yaşam şartları getirilmesi ve günün değişen koşullarına ve ihtiyaçlara uygun hale getirilmesi şeklinde açıklamak mümkündür. Kentsel dönüşüm uygulamaları kentsel stres faktörlerinden özellikle kentsel çevreden kaynaklı faktörlerin alt başlıklarından olan, mimari ve kentsel tasarım düzenleri, trafik sıkışıklığı, otopark problemleri, yeşil alanların varlığı ve ulaşılabilirliği, konut koşulları gibi alt başlıklara doğrudan etki edebilir. Fakat kentsel dönüşüm, amaçları ve boyutları ile ele alındığında ise kentsel stres faktörlerinin her bir başlığına etki edebileceği görülmektedir. Çünkü kentsel dönüşüm, çevresel, sosyal ve ekonomik açıdan çok yönlü bir uygulama yöntemi olarak kabul edilmektedir.

\subsection{Kentsel Dönüşümün Amaçları}

Kentsel dönüşümün amacı; kent için önem arz eden, ancak çeşitli nedenlerle çöküntüye uğramış, köhnemiş, eskimiş, bozulmuş ya da bu süreçlerin henüz yaşanmakta olduğu kent parçalarının yeniden hayata döndürülmesidir. Bu yönüyle hem çevresel hem de sosyal yönüyle kentlere etki etmektedir. Aynı zamanda kentsel dönüşüm, kentin kültürel mirasını ve kimliğini koruma ve yaşatma zorunluluğunun yanı sıra mevcut kaynakların kullanımının getireceği ekonomik kazançlarla da ilgilidir (Özden, 2008).

Kentsel dönüşüm faaliyet alanı ve doğası gereği mevcut kentin yapısına ve burada yaşayan bireylerin ekonomik, fiziksel ve sosyal geleceği üzerinden kentin bütün kimliğini etkileyeceğinden dönüşümü planlama çalışmalarında farklı disiplinlerin birlikte çalışmasını gerekli kılmaktadır. Bu bağlamda kentsel dönüşüm çalışmaları yapılırken 5 temel amaç gözetilerek tasarlanması gerektiği ifade edilmektedir (Şişman ve Kibaroğlu, 2009).
1.Kentin fiziksel koşulları ile toplumsal problemleri arasında doğrudan bir ilişki kurulmalı ve projeler temelde toplumsal bozulmanın önlemini sağlayacak şekilde geliştirilmeli.

2.Kentsel dönüşüm kentin hızla büyüyen, değişen ve bozulan dokusunda ortaya çıkan yeni fiziksel, toplumsal, ekonomik, çevresel ve alt yapısal ihtiyaçlara göre kentin sürekli yeniden gelişmesine olanak sağlayarak değişim ihtiyacına cevap vermelidir.

3.Kentsel dönüşüm projeleri fiziksel ve toplumsal çöküntü alanları haline gelen kent parçalarında ekonomik canlılığı yeniden getirecek stratejileri geliştirerek kentsel refah ve yaşam kalitesini arttırmayı hedeflemelidir.

4.Dönüşümde kentsel alanların en etkin bir biçimde kullanımına ve gereksiz kentsel yayılmadan kaçınmaya yönelik stratejiler ortaya koyularak projeler geliştirilmelidir. Böylece daha önce kullanılmış ve atıl olan alanların tekrar kullanımı sağlanacak ve gereksiz yayılma sınırlandırılmış olacaktır.

5.Toplumsal koşullar ve politik güçlerin ürünü olarak kentsel politikalarının şekillendirme ihtiyacını karşılamayı amaçlayarak çok paydaşlı bir planlama ve tasarım süreci ile gerçekleştirilmelidir. Kamu ve özel sektör katılımının yanı sıra sivil toplum örgütleri ve toplumun farklı kesimlerinin katılımını sağlayan bir planlama anlayışı benimsenmelidir.

$\mathrm{Bu}$ beş temel amaç, kentsel strese yol açan faktörlerin azaltılmasında ya da ortadan kaldırmasında rol oynayabileceğ teorik olarak değerlendirilebilir. Kentsel dönüşümün amaçlarının hangi stres faktörlerinin azaltılmasında ya da ortadan kaldırılmasında rol oynayabileceği Tablo 2'de gösterilmektedir.

Tablo 2'de görüldüğü üzere, kentsel dönüşümün her bir amacı farklı bir kentsel stres faktörüne etki etse de kentsel dönüşümün bütün amaçlarının uygulanması halinde kentsel stres faktörlerinin tamamında bir değişim görülebilecektir. Özellikle kentsel dönüşüm amaçlarının ikinci maddesi ile üçüncü maddesi kentsel stresin bütün faktörlerinde karşılık bulmaktadır. Kentsel stres ile kentsel dönüşüm uygulamalarının ortak kesişim noktaları kentsel dönüşüm amaçlarında da görüldüğü gibi, kentsel refah ve yaşam kalitesinin arttırılması ile kent ve toplumun ihtiyacına yönelik ortak adımların atılması yönündedir

Tablo 2. Kentsel dönüşümün amaçlarl ve etkilediği kentsel stres faktörleri (Şişman ve Kibaroğlu, 2009 ve Koene, 2018 referans alınarak tarafimızdan üretilmiştir.)

\begin{tabular}{|c|c|c|}
\hline Kentsel Dönüşümün Amaçları & Kentsel Stres Faktörü & Kentsel Stres Faktörleri Üzerindeki Olası Etkisi \\
\hline $\begin{array}{l}\text { Kentin fiziksel koşulları ile toplumsal } \\
\text { problemleri arasında doğrudan bir ilişki } \\
\text { kurulmalı ve projeler temelde toplumsal } \\
\text { bozulmanın önlemini sağlayacak şekilde } \\
\text { geliştirilmeli. }\end{array}$ & $\begin{array}{l}\text { Kentsel Çevreden } \\
\text { Kaynaklanan Faktörler } \\
\text { Kentlerin Durumundan } \\
\text { Kaynaklı Faktörler } \\
\text { Sosyal Yaşam Kaynaklı } \\
\text { Faktörler }\end{array}$ & $\begin{array}{l}\text { İklimsel Ve Jeofiziksel Tehlikelerin Dikkate Alınması, } \\
\text { Çöpler, Duvar Yazıları Ve Bakımsızlığın Azaltılması, } \\
\text { Mimari Ve Kentsel Tasarım Düzenlerinin Toplumun } \\
\text { Yapısına Göre Şekillendirilmesi, Konut Koşullarının } \\
\text { İyileştirilmesi, Güvenlik Hissinin Artması, Sosyal Destek } \\
\text { Ağlarının Arttırılması }\end{array}$ \\
\hline $\begin{array}{l}\text { Kentsel dönüşüm kentin hıla büyüyen, } \\
\text { değişen ve bozulan dokusunda ortaya } \\
\text { çıkan yeni fiziksel, toplumsal, ekonomik, } \\
\text { çevresel ve alt yapısal ihtiyaçlara göre } \\
\text { kentin sürekli yeniden gelişmesine } \\
\text { olanak sağlayarak değişim ihtiyacına } \\
\text { cevap vermelidir. }\end{array}$ & $\begin{array}{l}\text { Kentsel Çevreden } \\
\text { Kaynaklanan Faktörler } \\
\text { Sosyal Yaşam Kaynaklı } \\
\text { Faktörler } \\
\text { Ekonomik Kentsel } \\
\text { Faktörler } \\
\text { Sağlık Kaynaklı } \\
\text { Faktörler }\end{array}$ & $\begin{array}{l}\text { Mimari Ve Kentsel Tasarım Düzenlerinin İyileştirilmesi, } \\
\text { Yeşil Alanların Varlığının Sürdürülmesi Ve } \\
\text { Ulaşılabilirliğinin Arttırılması, Konut Koşullarının } \\
\text { İyileştirilmesi, Otopark Problemlerinin Çözümlenmesi, } \\
\text { Çöpler, Duvar Yazıları Ve Bakımsızlığın Giderilmesi, } \\
\text { Güvenlik Hissinin Artması, Sosyal Destek Ağlarının } \\
\text { Arttırılması, İşsizliğin Azaltılması, Aile Satın Alım Gücünün } \\
\text { Arttırılması, Egzersiz yapılabilmesi için alanların } \\
\text { düzenlenmesi, Fiziksel sağlığın iyileştirilmesi için mekan } \\
\text { kurgusu }\end{array}$ \\
\hline
\end{tabular}


Kentsel dönüșüm projeleri fiziksel ve toplumsal çöküntü alanları haline gelen kent parçalarında ekonomik canlılığ yeniden getirecek stratejileri geliştirerek kentsel refah ve yaşam kalitesini arttırmayı hedeflemelidir.
Dönüşümde kentsel alanların en etkin bir biçimde kullanımına ve gereksiz kentsel yayılmadan kaçınmaya yönelik stratejiler ortaya koyularak projeler geliştirilmelidir. Böylece daha önce kullanılmış ve atıl olan alanların tekrar kullanımı sağlanacak ve gereksiz yayılma sınırlandırılmış olacaktır.

Toplumsal koşullar ve politik güçlerin ürünü olarak kentsel politikalarının şekillendirme ihtiyacını karşılamayı amaçlayarak çok paydaşlı bir planlama ve tasarım süreci ile gerçekleştirilmelidir. Kamu ve özel sektör katılımının yanı sıra sivil toplum örgütleri ve toplumun farklı kesimlerinin katılımını sağlayan bir planlama anlayışı benimsenmelidir.
Kentsel Çevreden Kaynaklanan Faktörler Kentlerin Durumundan Kaynaklı Faktörler
Kentsel Çevreden Kaynaklanan Faktörler Kentlerin Durumundan Kaynaklı Faktörler Sosyal Yaşam Kaynaklı Faktörler Sağlık Kaynaklı Faktörler Ekonomik Kentsel Faktörler

Mimari Ve Kentsel Tasarım Düzenlerinin İyileştirilmesi,

Yeşil Alanların Varlığının Sürdürülmesi Ve

Ulaşılabilirliğinin Arttırılması, Konut Koşullarının

İyileştirilmesi, Otopark Problemlerinin Çözümlenmesi,

Çöpler, Duvar Yazıları Ve Bakımsızlığın Giderilmesi, Hava, Gürültü Ve Işık Kirliliğinin Azaltılması, Güvenlik Hissinin

Artması, Sosyal Destek Ağlarının Arttırılması, İşsizliğin Azaltılması, Aile Satın Alım Gücünün Arttırılması, Egzersiz yapılabilmesi için alanların düzenlenmesi, Fiziksel sağlığın iyileştirilmesi için mekan kurgusu

Sıkıcı Mega Yapıların Oluşturulmaması, Keskin Mimari Açılardan Kaçınılması, Mimari Ve Kentsel Tasarım Düzenlerinin İyileştirilmesi, Yeşil Alanların Varlığının Sürdürülmesi Ve Ulaşılabilirliğinin Arttırılması, Konut Koşullarının İyileştirilmesi, Otopark Problemlerinin Çözümlenmesi, Çöpler, Duvar Yazıları Ve Bakımsızlığın Giderilmesi, Hava, Gürültü Ve Işık Kirliliğinin Azaltılması, Güvenlik Hissinin Artması, İklimsel Ve Jeofiziksel Tehlikelerin Azaltılması

Sosyal Kaynakl1 Faktörler
Cinsiyet Eşitsizliğinin Ortadan Kaldırılması, Güvenlik

Hissinin Arttırılması, Suç Ve Hırsızlık Oranlarının Azaltılması, Sosyal Destek Ağlarının Arttırılması

\subsection{Kentsel Dönüşümün Boyutları}

Kentsel dönüşüm birden fazla boyutu bulunan çok yönlü bir uygulama yöntemidir. Kentsel dönüşümün boyutları; sosyal boyut, ekonomik boyut, planlama boyutu ve hukuki boyut olmak üzere dört ana başlık altında toplanmaktadır. Bütün boyutları ile ele alınması gereken bir bütün olan kentsel dönüşüm, amaçlarının yanı sıra boyutları ile de kentsel stres üzerinde etki etmektedir. İnsan, mekân ve istihdamın bir arada düşünülerek dönüşümün dört temel boyutunun bütünleşik ve dengeli bir şekilde geliştirilmesi kentsel dönüşümü başarılı kılan öğeler olarak kabul edilirken, kentsel dönüşüm projelerinde katılımcıların ve aktörlerin farklı olması nedeniyle yöntem ve uygulamalarda kurgunun iyi yapılması ve beklentilerin karşılanması dönüşümün başarısını etkileyen bir diğer etken olarak görülmektedir (Polat ve Dostoğlu, 2007). Tablo 3 'te kentsel dönüşümün boyutlarının kentsel stresin hangi faktörlerinin azaltılmasına katkı sağlayabileceği özet olarak belirtilmiştir.

Tablo 3. Kentsel dönüşümün boyutlarının etkilediği kentsel stres faktörleri (Özden, 2008 ve Koene, 2018 referans alınarak tarafimızdan üretilmiştir.)

\begin{tabular}{|l|l|l|}
\hline $\begin{array}{l}\text { Kentsel Dönüşüm } \\
\text { Boyutu }\end{array}$ & Etki Edebileceği Kentsel Stres Faktörü & Kentsel Stres Faktörlerinin Alt Başlıkları \\
\hline Sosyal Boyut & Sosyal Yaşam Kaynaklı Faktörler & $\begin{array}{l}\text { Eşitsizlik Hissi, Sosyal Destek Eksikliği Ve Sosyal } \\
\text { Güvenlik }\end{array}$ \\
\hline Ekonomik Boyut & Ekonomik Kentsel Faktörler & $\begin{array}{l}\text { Isssizlik, Kişi Başına Düşen Borç, Sosyal Güvenlik Ve } \\
\text { Satın Alım Gücü }\end{array}$ \\
\hline Planlama Boyutu & $\begin{array}{l}\text { Kentlerin Durumundan Kaynaklı Faktörler, } \\
\text { Kentsel Çevreden Kaynaklı Faktörler, Sağlık } \\
\text { Kaynaklı Faktörler }\end{array}$ & $\begin{array}{l}\text { Konut Koşulları, Yeşil Alanların Varlığı Ve } \\
\text { Ulaşılabilirliği, Mimari Ve Kentsel Tasarım Düzenleri, } \\
\text { Hava Kirliliği, Gürültü Kirliliği, Egzersiz Yetersizliğinin } \\
\text { Önüne Geçilmesi İçin Mekanların Üretimi Vb. }\end{array}$ \\
\hline Hukuki Boyutu & $\begin{array}{l}\text { Sosyal Yaşam Kaynaklı Faktörler } \\
\text { Kentsel Çevreden Kaynaklı Faktörler, } \\
\text { Kentlerin Durumundan Kaynaklı Faktörler }\end{array}$ & $\begin{array}{l}\text { Eşitsizliğin Olmamasimari Ve Kentsel Tasarım } \\
\text { Düzenlerinin Yasal Zeminde Tanımlı Olması, İklimsel } \\
\text { Durumun Ve Jeofiziksel Tehlikelerin Farkında Olunması }\end{array}$ \\
\hline
\end{tabular}

\footnotetext{
i. Sosyal Boyut

Dönüşüm alanlarında alınacak olan kararlar ve bu doğrultuda oluşturulacak stratejiler, yerel-toplumsal özellikler ile sıkı bir ilişki içindedir. Bu sebeple dönüşüm yapılacak alandaki toplumun iyi tanımlanması, yerel halkın ihtiyaçlarının ve bu ihtiyaçları e-ISSN: 2148-2683
}

karşılayacak faktörlerin belirlenmesi, ekonomik ve sosyal koşulların iyileştirilmesine yönelik ortak amaçların geliştirilmesi, toplumun içinden temsilcilerin seçilmesi, toplumsal girişimler, etkin toplumsal ortaklıklar gibi faktörler, dönüşüm alanlarında 
ayrıntılı ve kapsamlı bir şekilde ortaya konulmak durumundadırlar (Özden, 2008:219).

Dönüşümün sosyal boyutu; aktörler arasında sıkı ilişkilerin olması gerekliliğini, yerel halkın gereksinimlerinin doğru tespit edilerek bu gereksinimleri karşılayacak şekilde dönüşümün yapılması gerekliliğini ve sosyal ilişkilerin geliştirilmesini kapsamaktadır. Dönüşüm çalışmalarında yerel halkın çalışmalara katılması, sorunlarının ve çözüm önerilerinin dinlenmesi ve çalışmalarda dikkate alınması, kentsel dönüşümün başarıya ulaşma oranını artıracak ve yerel halkın projeyi benimsemesini sağlayacaktır. Bu nedenle dönüşümün sosyal boyutunun, kentsel strese yol açan faktörlerden eşitsizlik hissi, sosyal destek eksikliği ve sosyal güvenlik gibi faktörlerin bulunduğu sosyal kaynaklı faktörlerin azaltılmasında rol oynayabileceği öngörülmektedir.

\section{ii. Ekonomik Boyut}

Kentsel dönüşümde genel olarak büyük maliyetler gerekmekle birlikte, başarılı bir uygulamanın getireceği rant ile, bu maliyetler rahatlıkla geri kazanılabilmektedir. Bu nedenle, bir alanda dönüşüme karar vermeden önce, fayda-maliyet analizleri yapılmalı, maliyetin kesin hesabı çıkarılmalı ve elde edilecek rantın da projeksiyonu ortaya koyulmalıdır. (Özden, 2008:219).

Dönüşüme konu olacak bölgede yaşayan halkın veya o bölgede mülk sahibi olan kişilerin ekonomik durumları, dönüşüm uygulamasını etkileyen önemli faktörlerdendir. Dönüşüm uygulamasının finansmanının tamamının devlet tarafından karşılanması her zaman mümkün olamamaktadır. Bu nedenle, dönüşüme konu olacak bölgede yaşayan halkın ekonomik durumu ne kadar iyiyse, dönüşüm uygulamasının gerçekleşmesi de o kadar kolay olmaktadır (Kayacan, 2009).

Ekonomik durumu belirleyen en önemli faktörlerden biri olarak işsizlik karşımıza çıkmaktadır. İşsizlik oranının yüksek olduğu bir bölgede dönüşüm gerçekleştirmek oldukça zor olacaktır. Çalışmayan kişilerin ekonomik durumu kötü olacağından, dönüşüm yapılan bölgedeki yeni konutların ödemesini yapamayacak ya da dönüşüm sonrası gelişen bölgedeki yeni imkanlara ayak uydurmakta güçlük çekecektir. Böyle durumlarda devlet ve özel sektöre düşen görev, bu tür ekonomik olumsuzlukların giderilebilmesi için gerekli ekonomik koşulları sağlamak olacaktır. Düşük faizli kredi sağlamak, geri ödeme kolaylıkları sağlamak, teknik uzman ve personel temin etmek, eğitimi gerçekleştirmek, konut edinmede kolaylıklar sağlamak, gerekli danışmanlık hizmetlerini yerine getirmek bu koşullar arasında sayılabilir (Kayacan, 2009). Kentsel dönüşüm sonrasında yeniden kullanıma açılan/canlanan alanlar ile birlikte bölgede ticari hareketlilik de yeniden artmaya başlayacaktır. Bölgede bulunan esnaf/zanaatkarların da bölgenin hareketlenmesi ile birlikte işsizlik ve ekonomik sorunları azalacaktır.

Dönüşümün ekonomik boyutu; yerel halkın ekonomik durumunu, işsizlik oranlarını, bölgedeki ticari faaliyetlerin durumunu kapsamaktadır. Dönüşüm yapılacak alanda yaşayan halkın ekonomik durumları, işsizlik oranları göz önünde bulundurularak, sağlanacak ekonomik destekler ve dönüşüm alanında ticari aktivitelerin düzenlenmesi/artırılması ile birlikte halkın ekonomik durumuna katkı sağlanabilecektir. Bu nedenle dönüşümün ekonomik boyutunun, kentsel strese yol açan faktörlerden işsizlik, kişi başına düşen borç, sosyal güvenlik ve satın alım gücü faktörlerinin bulunduğu ekonomik kentsel stres faktörlerinin azaltılmasında rol oynayabileceği öngörülmektedir.

iii. Planlama Boyutu
Kentsel dönüşümü somutlaştıran ve hayata geçmesini sağlayan planlamadır. Kentlerin canlandırılmasında, bu planlamanın ve tasarımın bütüncüllüğü, sürdürülebilirliği, yaşam kalitesini arttırıcı tedbirleri olmalı, özgünlüğü ifade edebilmelidir (Özden, 2008: 218). Kentsel dönüşüm sürecinde değerlendirilecek alanın iddia sahipleriyle birlikte dönüşüm planını geliştirmeyi hedeflediği boyut olan planlamada dönüşüm planının hazırlanması üç kısımdan oluşmaktadır. Birinci kısımda ilgi sahibi analizi yapılmakta; analizi takiben ilgi sahibi gruplarıyla bilişsel haritaları oluşturulmakta; son aşamada da önceki aşamalarda elde edilen veriler tüm ilgi gruplarıyla paylaşılmakta, değerlendirilmekte, alan ile ilgili kentsel dönüşüm vizyonu, stratejileri, öncelikli projeler saptanmakta ve detaylandırılmaktadır. Projelerin detaylandırılmasıyla eylem planları hazırlanmaktadır. Burada ilgi gruplarının karar alma ve uygulama aşamalarına katılmaları, bu aktörlerin gelecek modellerin oluşturulmasında hak iddia eden aktörler durumuna getirilmeleri bakımından önem arz etmektedir. Nitekim onların tasarım sürecine girdi oluşturmaları, oluşturulacak planın işlerlik kazanmasında duyarlılıkları ve taahhütleri açısından önemlidir. Kentsel dönüşüm tasarım ve planlama çalışmalarına eş zamanlı ve sürekli olarak hem tüm proje grup üyeleri arasında hem de genel halkla iletişim ve geribildirim süreci yürütülmelidir (Ataöv ve Osmay, 2007: 77).

Yine bölgede yer alan boş alanların değerlendirilmesi, bölgeyi çekici hale getirecek, yaşam kalitesini ve standartlarını artıracak çalışmaların yapılması, kentsel tasarım çalışmalarını gerektirmektedir. Cadde ve sokakların düzenlenmesi, meydan, yeşil alan, parklar ve rekreasyon alanlarının düzenlenmesi, ticari alanların düzenlenmesi gibi pek çok çalışma kentsel tasarım çalışmalarının bünyesinde yapılmaktadır (Kayacan, 2009).

Dönüşümün planlama boyutu; dönüşüm yapılacak alanın altyapısı, ulaşımı, boş alanların değerlendirilmesi, yaşam kalitesini ve standartlarının artırılması, cadde ve sokakların düzenlenmesi, yeşil alanlar, parklar ve rekreasyon alanlarının düzenlenmesi, ticari alanların düzenlenmesi gibi çalışmaları kapsamaktadır. Altyapının ve ulaşımın geliştirilmesi, cadde ve sokakların düzenlenmesi, halkın nefes alıp sosyalleşebileceği ve günün stresinden uzaklaşabileceği yeşil alanların ve rekreasyon alanlarının düzenlenmesi, bölgenin yaşam kalitesini ve standartlarını da artıracaktır. Bu nedenle dönüşümün planlama boyutunun, kentlerin durumundan ve kentsel çevreden kaynakl faktörlerin ve sağlık kaynaklı faktörlerin azaltılmasında rol oynayabileceği öngörülmektedir.

\section{iv. Hukuki Boyut}

Kentsel dönüşüm, ancak ilgili kanunların birbiriyle örtüşmesi ya da birbirini tamamlaması durumunda hayata geçebilmektedir. $\mathrm{Bu}$ bağlamda kanunların kentsel dönüşüm uygulamaları için düzenleyici ve darboğazları giderici maddeler içererek, birbirlerini tamamlayıp bütünlemeleri gerekmektedir (Özden, 2008:219).

Hukuki boyutu yönüyle kentsel dönüşüm değerlendirildiğinde, herkes için eşit hakların tanındığı bir yasal zemine sahip olması gerekmektedir. Mimari ve kentsel tasarım düzenleri üzerinde açıklayıcı maddelerin yanı sıra kentsel dönüşüm uygulanacak alana dair iklimsel yapının ve jeofiziksel tehlikelerin göz önünde bulundurulması zorunluluğu yasal altlıkta yer almalıdır. Bu nedenler ile dönüşümün hukuki boyutu, sosyal yaşam kaynaklı faktörler, kentsel çevreden kaynaklanan faktörler ve kentlerin durumundan kaynaklı faktörlerin azaltılmasında rol oynayabilecektir. 


\section{Uygulanmış Örneklerinden \\ Kentsel \\ Dönüșüm Stresin Azaltılmasına Yönelik Uygulama Örnekleri}

\subsection{Bo01 (City of Tomorrow) Malmö}

Bo01- "City of Tomorrow” projesi İsveç’in Malmö kentinde 1995 yılında yapımına başlanmış 2001 yılında tamamlanmış liman alanının karma kullanımlı yeni bir yaşam alanına sürdürülebilir eko-kent ilkeleri bağlamında dönüştürülmesi projesidir. Bölgenin ilk etap olarak belirlenen arazisi, küçük geliștirme parselleri olarak, farklı mimarlık firmalarına bırakılarak kaliteli malzemelerin kullanıldı ğı, enerji verimliliği sağlayan ve belirli çevre standartlarına göre inşa edilmiş evlerden oluşmaktadır (Url-1) (Şekil 1).

Sürdürülebilir kentsel tasarım yaklaşımları için ilk İsveç modellerinden biri olarak Bo01'in geliştirilmesine yönelik düşünce ve yeni yaklaşımlar, hükümet politikası ve finansman sağlayan girişimler sayesinde mümkün olmuştur (Austin,2013). Yapılan uygulamalar arasında öne çıkan ekolojik tasarımların yanı sıra trafikle ilgili sorunları azaltmak için yeni kaldırımlar ve bisiklet yolları inşa edilmiş ve sakinler tarafından yerel bir elektrikli araba havuzu kurulmuştur (Url-1). Yeşil alanların genişletilmesi ve açık yağmur suyu yönetim sistemi ile biyoçeşitlilik artırılmıştır (Url-1).

Şekil 1. Bo01 proje alanından bir görüntü (Url-2)

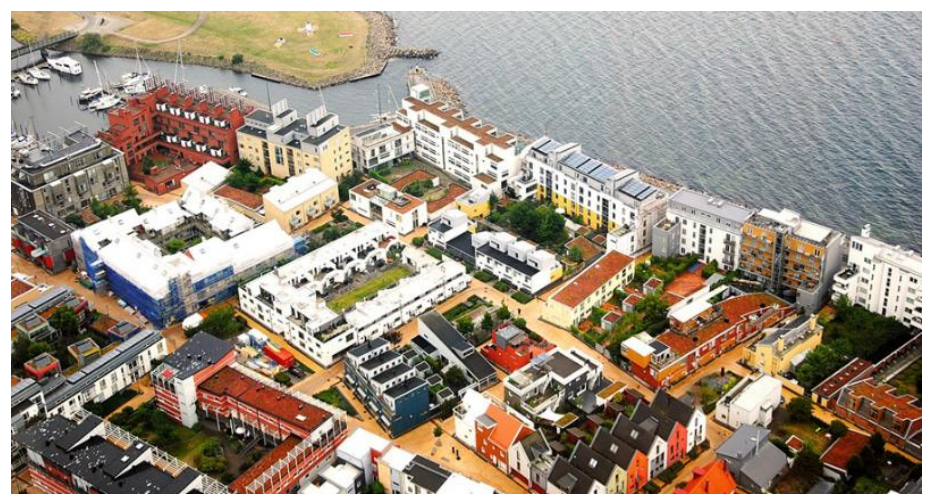

Batı Limanı bölgesinde yer alan Bo01 projesi, kentsel dönüşüm projesi başlamadan önce gemi inşa endüstrisine ev sahipliği yapmaktadır (Şekil 2). Başlatılan dönüşüm projesi sonrasında farklı birçok girişim ile konut projeleri, yerel yönetim ile kamusal alanların düzenlendiği bir ekolojik, sürdürülebilir kentsel tasarım projesi haline gelmiştir (Şekil 3).

Tek bir yap1 formundan oluşmayan Bo01 projesi, sürdürülebilir ekolojik kentsel dönüşüm ve tasarım yaklaşımlarıyla, Malmö kentine yeni bir yaşam alanı oluşturmuştur. Kentsel dönüşüm projelerinin genel amaçları ile tamamen uyumlu oluşturulan proje amaçları bakımından yalnızca Malmö kenti için değil Dünya çapında inceleme konusu olmuştur (Fraker,2013). Projenin temel amaçları incelendiğinde kentsel stresi azalttığı görülmektedir (Tablo 4). Kentlerin durumundan kaynaklı faktörler, kentsel çevreden kaynaklanan faktörler, sosyal yaşam kaynaklı faktörler, sağlık kaynaklı faktörler ve ekonomik kentsel faktörlerin tamamına yönelik kentsel stresi azaltıcı etki bulunmaktadır.
Şekil 2. Dönüşüm projesi başlamadan önceki durum (Fraker, 2013)

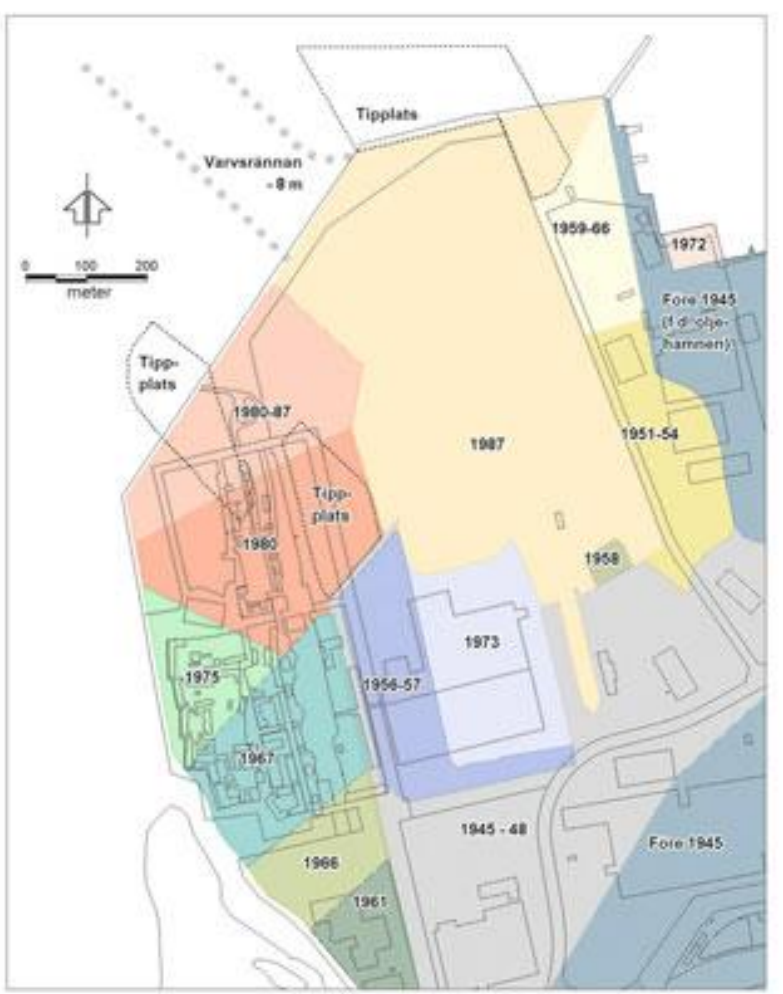

Şekil 3. Dönüşüm projesinden sonra vaziyet planı (Fraker, 2013)

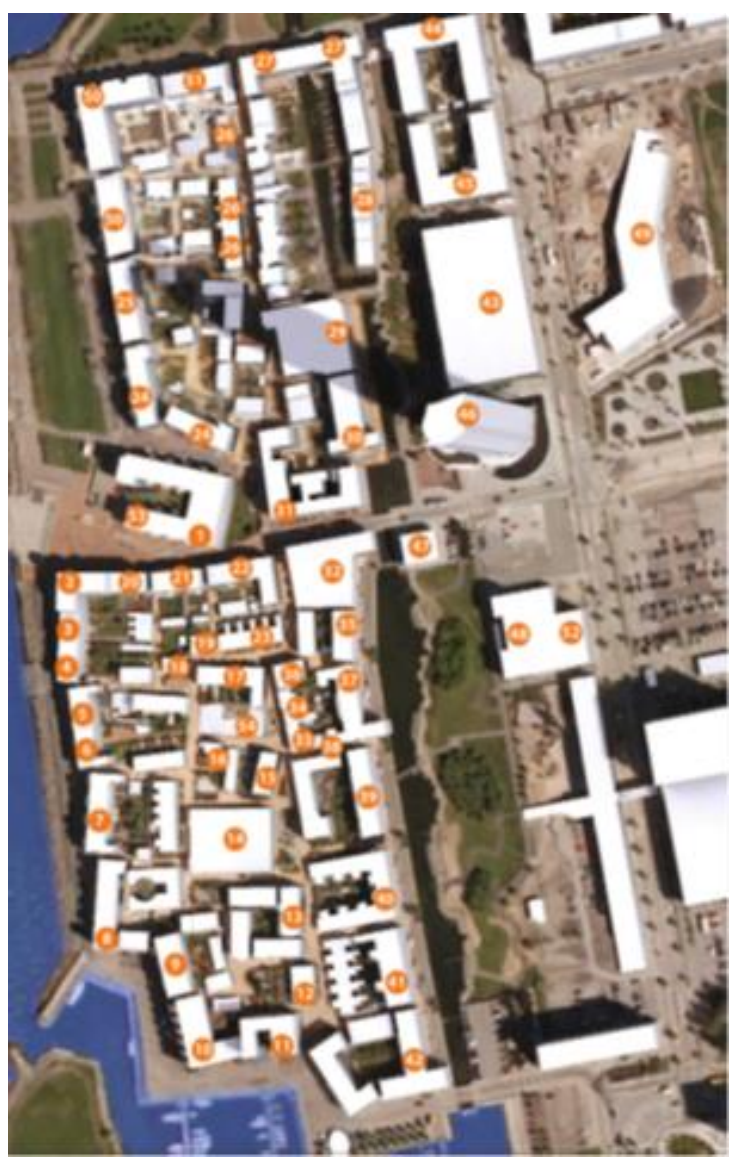



üretilmiştir.)

\begin{tabular}{|c|c|c|c|c|}
\hline $\begin{array}{l}\text { Proje } \\
\text { Adı ve } \\
\text { Yeri }\end{array}$ & $\begin{array}{l}\text { Projenin amaçları } \\
\text { (Fraker,2013) }\end{array}$ & Kentsel Stres Faktörü & $\begin{array}{l}\text { Etki Ettiği Kentsel Stres Faktörü Alt } \\
\text { Bileşenleri }\end{array}$ & $\begin{array}{l}\text { Kentsel } \\
\text { Strese } \\
\text { Etkisi }\end{array}$ \\
\hline \multirow{7}{*}{$\begin{array}{l}\text { Bo01, } \\
\text { Malmö } \\
\text { İsveç }\end{array}$} & Çevresel etkiyi azaltmak. & $\begin{array}{l}\text { Kentlerin Durumundan } \\
\text { Kaynaklı Faktörler }\end{array}$ & $\begin{array}{l}\text { Hava, gürültü ve sşık kirliliğinin } \\
\text { azaltılması, iklimsel tehlikelerin dikkate } \\
\text { alınmas1 }\end{array}$ & Azalticı \\
\hline & $\begin{array}{l}\text { Enerji verimliliğini arttırmak } \\
\text { ve Yenilenebilir hammadde } \\
\text { kullanımını desteklemek. }\end{array}$ & $\begin{array}{l}\text { Kentsel Çevreden } \\
\text { Kaynaklanan Faktörler }\end{array}$ & $\begin{array}{l}\text { Mimari ve kentsel tasarım düzenlerinin } \\
\text { toplumun yapısına göre şekillendirilmesi, } \\
\text { konut koşullarının iyileştirilmesi, }\end{array}$ & Azalticı \\
\hline & $\begin{array}{l}\text { Yeniden kullanım ve geri } \\
\text { dönüşümü arttırmak }\end{array}$ & $\begin{array}{l}\text { Kentsel Çevreden } \\
\text { Kaynaklanan Faktörler }\end{array}$ & $\begin{array}{l}\text { Çöplerin azalması, mimari ve kentsel } \\
\text { tasarım düzenlerinin toplumun yapısına } \\
\text { göre şekillendirilmesi, }\end{array}$ & Azalticı \\
\hline & $\begin{array}{l}\text { Biyoçeşitliliği korumak ve } \\
\text { güçlendirmek. }\end{array}$ & $\begin{array}{l}\text { Kentsel Çevreden } \\
\text { Kaynaklanan Faktörler }\end{array}$ & Yeşil alanların varlığının sürdürülmesi & Azalticı \\
\hline & $\begin{array}{l}\text { Tehlikeli kimyasalların } \\
\text { kullanımını azaltmak. }\end{array}$ & $\begin{array}{l}\text { Sağlık Kaynaklı } \\
\text { Faktörler }\end{array}$ & $\begin{array}{l}\text { Mikrop, bakteri ve virüslere maruz kalma } \\
\text { endişesinin azaltılması }\end{array}$ & Azaltıcı \\
\hline & $\begin{array}{l}\text { Yeni iş imkanları } \\
\text { oluşturmak. }\end{array}$ & $\begin{array}{l}\text { Ekonomik Kentsel } \\
\text { Faktörler }\end{array}$ & $\begin{array}{l}\text { İşsizliğin azaltılması, aile satın alım } \\
\text { gücünün arttırılması }\end{array}$ & Azaltıc1 \\
\hline & $\begin{array}{l}\text { Sürdürülebilir kalkınmaya } \\
\text { geçişte insanların katılımını } \\
\text { teşvik etmek ve } \\
\text { kolaylaştırmak }\end{array}$ & $\begin{array}{l}\text { Sosyal Yaşam Kaynaklı } \\
\text { Faktörler }\end{array}$ & $\begin{array}{l}\text { Cinsiyet eşitsizliğinin ortadan } \\
\text { kaldırılması, güvenlik hissinin } \\
\text { arttırılması, sosyal destek ağlarının } \\
\text { arttırılması }\end{array}$ & Azaltıcı \\
\hline
\end{tabular}

Proje kentsel dönüşüm boyutları yönüyle ele alındığında sosyal yaşam kalitesinin arttırılması, ekonomik açıdan yeni istihdam alanları yaratması ve ticaret hayatının yanı sıra turistik açıdan getirisi de alanı canlandırmışıtır. Planlama boyutu ile birçok farklı projeye ilham kaynağı olan proje sürdürülebilir kentsel tasarım ilkelerinin örneklerinden biri haline gelmiştir. Hukuki yönüyle hükümet politikalarına bağlı olarak uygulanmış olması ve girişimcilerin finansman desteği ile getirisi yüksek bir proje olmuştur. Ayrıca proje yenilenebilir enerji kaynaklarına yönelik attığı adımlar ile enerji verimliliği açısından avantajlı konuma geçmiştir. Tablo 5'te kentsel dönüşümün boyutlarının proje bağlamında ele alınarak kentsel stres faktörleri üzerindeki etkisi belirlenmektedir.
Amaçlarında olduğu gibi boyutları ile de ele alındığında Bo01 kentsel dönüşüm projesi kentsel stresin azaltılmasında öncü bir proje niteliği taşımaktadır. Liman ve tersane bölgesinin sürdürülebilir bir kentsel yaşam alanına çevrildiği projenin çok yönlü ele alınan boyutları yerel halka ve Malmö yerel yönetimine kazanım olarak geri dönmüştür. Ölçülen performans temelinde Bo01, küçük bir kentsel mahalle ölçekli proje için enerji arzının yüzde 100'ünü yerel, yenilenebilir kaynaklardan sağlamanın mümkün olduğunu göstermektedir (Fraker, 2013).

Tablo 5. Projenin kentsel dönüşüm boyutlart ve kentsel stres faktörlerine etkisi (Özden, 2008, Fraker, 2013 ve Koene, 2018 referans alınarak tarafimızdan üretilmişstir.)

\begin{tabular}{|c|c|c|c|c|}
\hline $\begin{array}{l}\text { Proje } \\
\text { Adı ve } \\
\text { Yeri }\end{array}$ & $\begin{array}{l}\text { Projenin } \\
\text { boyutları }\end{array}$ & Kentsel Stres Faktörü & Etki Ettiği Kentsel Stres Faktörü Alt Bileşenleri & $\begin{array}{l}\text { Kentsel } \\
\text { Strese } \\
\text { Etkisi }\end{array}$ \\
\hline \multirow{4}{*}{$\begin{array}{l}\text { Bo01, } \\
\text { Malmö } \\
\text { İsveç }\end{array}$} & $\begin{array}{l}\text { Sosyal } \\
\text { Boyut }\end{array}$ & Sosyal Yaşam Kaynaklı Faktörler & $\begin{array}{l}\text { Yerel halkın planlamaya katılması sağlanması yoluyla } \\
\text { cinsiyet eşitsizliğinin ortadan kaldırılması, güvenlik } \\
\text { hissinin arttırılması }\end{array}$ & Azaltic1 \\
\hline & $\begin{array}{l}\text { Ekonomik } \\
\text { Boyut }\end{array}$ & Ekonomik Kentsel Faktörler & $\begin{array}{l}\text { Yeni iş imkanları oluşturularak işsizlik azaltılıış, } \\
\text { yenilenebilir enerji kullanımı ve geri dönüşüm bilinci } \\
\text { kazandırılarak ailenin satın alım gücü arttırılması }\end{array}$ & Azaltic1 \\
\hline & $\begin{array}{l}\text { Planlama } \\
\text { boyutu }\end{array}$ & $\begin{array}{l}\text { Kentlerin Durumundan Kaynaklı } \\
\text { Faktörler, Kentsel Çevreden } \\
\text { Kaynaklı Faktörler, Sağlık } \\
\text { Kaynaklı Faktörler }\end{array}$ & $\begin{array}{l}\text { Yeşil alanların varlı̆̆ının arttırılması, deniz ile } \\
\text { erişilebilirliğin arttırılması, farklı mimari yapılar ile } \\
\text { mimari sıkıcılıktan kurtulması, sürdürülebilir kentsel } \\
\text { tasarım ile yağmur suyundan, enerjiye toplu ulaşımdan } \\
\text { bisiklet kullanımının yaygınlaştırılması ile trafiğin } \\
\text { azaltılmasına katkı sağlanması }\end{array}$ & Azaltici \\
\hline & $\begin{array}{l}\text { Hukuki } \\
\text { boyut }\end{array}$ & $\begin{array}{l}\text { Sosyal Yaşam Kaynaklı Faktörler, } \\
\text { Kentsel Çevreden Kaynaklı } \\
\text { Faktörler, Kentlerin Durumundan } \\
\text { Kaynaklı Faktörler }\end{array}$ & $\begin{array}{l}\text { Hükümetin politikaları doğrultusunda katıllımcılık } \\
\text { ilkesi ile hem üniversitenin hem girişimcilerin hem de } \\
\text { yerel halkın birlikte projeyi şekillendirmesi, Dünya } \\
\text { çapında örnek oluşturması }\end{array}$ & Azaltici \\
\hline
\end{tabular}




\section{Sonuç ve Değerlendirme}

Dünya genelinde bireyler, kendilerini sürekli bir şekilde baskı altında hissetmektedirler. Bu baskının yarattığı stres ise yalnızca bireylerin sağlığını değil toplumun da yaşantısını doğrudan etkilemekle birlikte yaşam kalitesini de düşürmektedir. Toplumsal baskının yarattığı etkiler ile ilgilenen kentsel stres, faktörleri ile birlikte ele alınması gereken önemli bir konudur. Literatürde tam anlamıyla tanımı olmasa da kentli nüfusun her gün hayatlarının bir parçası olarak kentsel stres, çevresel, ekonomik ve sosyal anlamda sağlıklı yaşam koşullarına etki etmektedir. Bu çalışma ile de kentsel stres konusu üzerinde farkındalık oluşturmak ve gelecekte de kentsel stres konusunun yapilacak projelerde ele alınması gereken önemli bir parametre halinde düşünülmesi gerektiği vurgulanmaktadır. Kentsel stresin azaltılmasına yönelik atılacak adımların geleceğin kentleri ve kentlileri için her yönüyle önemi bulunmaktadır. Özellikle yerel yönetimler ile hükümetlerin toplumun refah seviyesini arttırıcı çözüm önerileri kentsel stresin azaltılması için birer firsat haline gelecektir.

Bir uygulama aracı olarak gerek yerel yönetimler gerekse hükümetin başvurduğu kentsel dönüşüm, doğru uygulandığında, sağlıksız koşulların iyileştirilmesi, yaşam kalitesinin arttırılması gibi sonuçlar yaratmakta olup kentsel stres faktörlerinin azaltılmasında anahtar bir rol üstlenebilmektedir. Kentsel dönüşümün teorik olarak gerek amaçları gerek boyutları incelendiğinde kentsel strese yol açan faktörlerin azaltılmasında ya da tamamen ortadan kaldırılmasında rol oynayabileceği açık olarak görülmektedir. Özellikle sosyal yaşam kaynaklı, ekonomik kentsel faktörler, kentlerin durumundan ve kentsel çevreden kaynaklı stres faktörlerinin neredeyse tamamı, kentsel dönüşüm uygulamaları ile önlenebilecek veyahut azaltılabilecek olduğu görülmektedir. Kentsel dönüşümün amacına uygun olarak gerçekleştirilmesi, sosyal ve ekonomik boyutlarının yanı sıra yerel halkın da değerlendirilerek sürece katılması, onların ihtiyaç ve taleplerine cevap vermesi de son derece önem arz etmektedir.

Çalışma kapsamında ele alınan, Bo01 Malmö, ekonomik cazibesini kaybetmiş bir liman alanı iken, Dünya çapında başarılı bir kentsel dönüşüm projesi olarak sürdürülebilir ve ekolojik karma bir yaşam alanı ile kentsel stresin azaltıldığı bir örnektir. Belirlenen genel amaçları ile ele alınan kentsel dönüşüm boyutları ile kentsel stres faktörlerinin tamamında azaltıcı etkiler oluşturduğu görülmüşsür. Bo01 projesinde ele alınan amaçlar gibi sürdürülebilir ve ekolojik temelli çalışmalar ve kentsel dönüşüm projeleri ile kentsel stresin azaltılması mümkün olacaktır. Araştırma kapsamında ele alınan bu kentsel dönüşüm projesi kentsel stres yönüyle düşünülmese de uygulamada ortaya konan sonuçları ile kentlilerin stres seviyesini azaltmayı başarmıştır. Sonuçta başarılı olarak görülen, Bo01 kentsel dönüşüm projesi kentsel stresin azaldığı, yaşam kalitesinin yüksek olduğu bir yerleşim alanına dönüşmüştür. Bo01 projesinde olduğu gibi sürdürülebilir ve ekolojik planlama ilkeleri ve doğru kentsel dönüşüm uygulamaları ile kentsel stresin azaltılmasına yönelik atılacak adımlar yaşam kalitesini arttıracağı gibi kentin yapısına da olumlu katkılar sunabilecektir. Gelecekte de kentsel dönüşüm projelerinin kentsel stres faktörlerini gözeterek ele alındığında daha kaliteli ve stresten arındırılmış yaşam alanlarını oluşturmak mümkün olabilecektir.

\section{Kaynakça}

Austin, G. (2013). "Bo01, Malmö, İsveç Örneği Ve Sürdürülebilirlik Değerlendirmesi". Yeşil Bina Dergisi. 8(3): 34-50. doi: 10.3992 / jgb.8.3.34. ISSN1552-6100.

ATAÖV, A., OSMAY, S. (2007), “Türkiye'de Kentsel Dönüşüme Yöntemsel Bir Yaklaşım”, Middle East Technical University Journal of The Faculty of The Architecture, Vol. 2, 57-82.

Fraker, H. (2013). The hidden potential of sustainable neighborhoods: Lessons from low-carbon communities (pp. 150-155). Washington, DC, USA: Island press.

Kayacan, T. (2009). Gecekondu Alanlarının Kente Entegrasyonu, Zeytinburnu ve Karanfilköy Örnekleri, Yüksek Lisans Tezi, İTÜ, İstanbul.

Koene, M. (2018). Urban Stress: Research into the reduction of urban stress through urban design, MSc Thesis, TU Delft, The Netherlands.

Özden, P. P. (2008). "Kentsel Yenileme: Yasal-Yönetsel Boyut, Planlama ve Uygulama", İmge Kitabevi Yayınları, İstanbul

Polat, S., Dostoğlu N. (2007). "Kentsel Dönüşüm Kavramı Üzerine: Bursa'da Kükürtlü ve Mudanya Örnekleri”. Uludağ Üniversitesi Mühendislik-Mimarlık Fakültesi Dergisi, Cilt 12, Sayı 1, 61-76.

Şişman, A., Kibaroğlu, D. (2009). 12. Türkiye Harita Bilimsel ve Teknik Kurultayı. "Dünya'da ve Türkiye'de Kentsel Dönüşüm Uygulamaları", Ankara: TMMOB Harita ve Kadastro Mühendisleri Odası.

Yedekçi, G. (2015). Dünya'da ve Türkiye'de Uygulanmış Örnekleri ve Özgün Dönüşüm Modeli Önerisi İle Kentsel Dönüşüm. Mimarlık Vakfi İktisadi İşletmesi.

Url-1. https://use.metropolis.org/case-studies/city-of-tomorrow

Url-2. https://www.flickr.com/photos/mariaeklind/14808414873/ 